\title{
Underrepresentation of Women in Labour Force, Comparatively Sweden and Turkey
}

\section{GÜLIZ ÖZTÜRKMEN}

Independent researcher, Turkey.

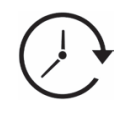

Article History

Received: 08 March

2021

Accepted: 04 May 2021

\author{
Keywords \\ Job quality; \\ Labour force; \\ Socio-economic factors; \\ Sweden; \\ Turkey; \\ (under) Representation \\ of women.
}

\section{Introduction}

Women's participation in the labour force has been gaining importance in the European Union (EU) in recent years. Employment policies have been one of the key criteria in EU legislation under Chapter 19-Social Policy and Employment to integrate women into the labour market and enhance gender equality. ${ }^{1}$ Social Policy and Employment Chapter aims to create policies which tries to improve people's living/working conditions, increase employment of men and women, improve the quality of the jobs and it also aims to promote gender equality in employment. ${ }^{2}$ Underrepresentation of women in labour force is also an important subject under Chapter 19. International Labour Organization mentions that finding a job is much more difficult for women than it is for men. Women usually work in low quality jobs and benefit from limited social rights. ${ }^{3}$

Ozturkmen, G. (2021)

${ }^{2}$ Directorate for EU Affairs, Turkey (2020). Chapter 19 Social Policy and Employment.

${ }^{3}$ International Labour Organization (2018). The Gender Gap in Employment: What's Holding Women Back? Retrieved on 6 6 th February 2021, from https://www.ilo.org/infostories/en-GB/Stories/ Employment/barriers-women\#intro

CONTACT Güliz Öztürkmen $\gtrsim$ gulizozturkmen@yahoo.com $\boldsymbol{Q}$ Independent researcher, Turkey.

\section{(c) (i)}

(c) 2021 The Author(s). Published by Enviro Research Publishers.

This is an Open Access article licensed under a Creative Commons license: Attribution 4.0 International (CC-BY).

Doi: http://dx.doi.org/10.12944/CRJSSH.4.1.06 
It is stated that women are less likely to participate in the labour force than men. For instance, in 2019 less than half of all women (47.7 percent) and nearly 74.7 percent men participated in the labour force globally. ${ }^{4}$ The reasons of this gender gap are usually the cultural restrictions and structural barriers. Additionally, women's education level, labour market conditions, their responsibilities at home, temporary or short-term contracts for women, rights of women in the labour market, the level of income or insufficient social protection rights, social norms and economic incentives also affect labour force representation of women. ${ }^{5}$ Besides these reasons, job quality is another important factor which may influence women's labour force participation or representation. The main idea here is not only to create more jobs but also provide better jobs. ${ }^{6}$ Following this, high quality jobs foster the well-being of the workers through wages and other rewards, pension, security and job control (ability to choose). It has been argued that low job quality can affect female participation in the labour force, probably leading to an underrepresentation of women in the labour market. ${ }^{7}$ Due to job quality and other various factors stated above countries experience differences in labour force participation of women. Besides this, a country's social, economic, political and cultural situation effects the status of women in that country. Torun states that developing countries still could not offer equal opportunities for its citizens. ${ }^{8}$ According to the OECD, low labour force participation of women, informality, rigid employment rules and low-quality employment are economic challenges in Turkey that should be addressed. ${ }^{9}$ For instance workers work informally due to high employment costs and a large amount of population work for net minimum wage of $2.825,90 \mathrm{TL}$ in Turkey. ${ }^{10}$ OECD mentions that prior to Covid-19 crisis in Turkey, "GDP per capita is $46 \%$ lower than OECD best performers. Productivity is $30 \%$ lower than OECD best performers. Employment rate is low and was decreasing before the 2020 crisis. Inequality is higher than in most advanced economies. The poorest $20 \%$ of households earn $6.1 \%$ of total income". In Sweden "GDP per capita is equal with OECD best performers. Productivity is $8 \%$ higher than OECD best performers. Employment rate is high but was decreasing before the 2020 crisis. Inequality is lower than in most advanced economies. The poorest $20 \%$ of households earn $8.9 \%$ of total income". OECD states that for Turkey, reducing the cost of employment of the low skilled, providing equal education for all, reforming the legislation of employment protection and strengthening labour market policies especially the informal sector, easing the burdens and barriers to foreign investment and trade should be assumed primarily for the structural reform. On the other hand, Sweden takes action to strengthen Swedish economy and to arrange migrant integration and taxation.

Besides its economy Turkey exerts substantial effort to increase the life quality of its citizens. Turkey is good at civic engagement however she should increase it social values such as wealth, skills, health, social connections, education, wellbeing, work-life balance and personal security of its citizens. ${ }^{11} \mathrm{Job}$ is one of the main factors on quality of life which leads to economic and social freedom and gives power for people to implement their aspirations. ${ }^{12}$ For OECD, educated population is necessary for social and economic well-being. Turkey should invest more on peoples' education for socially and economically strong life. In Turkey, $39 \%$ of adults aged $25-64$ have completed upper secondary education which is lower than the OECD average of $78 \% .{ }^{13}$ Following this, health is another crucial factor in a well-established social life. Healthy person has more potential to produce, participate in education, being in labour market and to engage

\footnotetext{
${ }^{4}$ Catalyst (2020). Women in the Workforce-Global: Quick Take. Retrieved on $6^{\text {th }}$ February 2021, from https://www.catalyst.org/research/women-in-the-workforce-global/

${ }_{5}^{5}$ Jaumotte, F (2004). Labour Force Participation of Women: Empirical Evidence on the Role of Policy and Other Determinants in OECD Countries. Retrieved on $12^{\text {th }}$ September 2020 , from http://www.oecd.org/social/labour/34562935.pdf

${ }^{6}$ Dahl, S., Nesheim, T. and Olsen, K.M. (2009). Quality of work - concept and measurement. Retrieved on $12^{\text {th }}$ September 2020, from https://era.ed.ac.uk/bitstream/handle/1842/3146/RECWP_0509_Dahl_Nesheim_Olsen.pdf;jsessionid=576F0E1C7D45F7112B49A81248AF4A66?sequence=1

${ }^{7}$ FAWCETT (Working for Women's Rights since 1866) (2013). The Changing Labour Market: Delivering for Women, Delivering for Growth. Retrieved on 12 $2^{\text {th }}$ September 2020, from https://www. fawcettsociety.org.uk/the-changing-labour-market-delivering-for-women-delivering-for-growth

${ }^{8}$ Torun, E. H. L. I. N. A. Z. (2010). Socio-economic status of women according to development levels of countries and structure in Turkey. African journal of agricultural research, 5(11), 1154-1161. ${ }^{9}$ OECD (2021). Economic Policy Reforms 2021: Going for Growth, p.1.

${ }^{10}$ Ministry of Labour and Social Security (2021). Calculation of Net Minimum Wage and its Cost for Employers. Retrieved on 1st May 2021, from https://www.csgb.gov.tr/asgari-ucret/

"OECD (n.d.). Turkey: How's Life? Retrieved on 1st May 2021, from http://www.oecdbetterlifeindex.org/countries/turkey/

${ }^{12}$ Eurostat (2015). Quality of Life: Facts and views. Luxembourg: Publications Office of the European Union.

${ }^{13}$ OECD (n.d.). Turkey: How's Life? Retrieved on 1st May 2021, from http://www.oecdbetterlifeindex.org/countries/turkey/
} 
in social life. ${ }^{14}$ According to OECD data regarding health, life expectancy at birth is 78 years in Turkey.

Sweden performs more successfully in social values like wealth, health, education and well-being. OECD indicates that in Sweden $77 \%$ of people aged 1564 have a paid job. $83 \%$ of adults aged $25-64$ have completed upper secondary education which is higher than the OECD average of $78 \%$. According to OECD data regarding health, life expectancy at birth is 82 years in Sweden.

Labour force participation of women is important for sustainable economic development, especially in countries with highly educated women. ${ }^{15}$ It is also important for female empowerment in all the areas of the society. However female employment is still low especially in higher positions and women usually work in low paid or part-time jobs. ${ }^{16}$ In fact, this fact is directly related with gender inequality, so it is important to pay attention for men and women inequality. In business life men are usually in the front and women usually can not reach men in many sectors. For instance, in Turkey women are mostly represented in agricultural and in informal jobs. More importantly they are stigmatized as child carers or elderly carers which mostly leaves them behind men. In Turkey labour force participation of women between 15-64 years old is 38 percent and it is 82 percent in Sweden in 2020. ${ }^{17}$

In Sweden in 2019 labour force participation of women increased from 44000 to 2594000 and labour force participation of men increased from 38 000 to $2860000 .{ }^{18}$ This shows that the participation rate among women rose to 70.4 percent and among men it rose to 75 percent. In 2019 in Turkey labour force participation of women is 33 percent while it is 71 percent for men. ${ }^{19}$ In Turkey women are usually out of the labour market and the ones who are in the labour market work informally. ${ }^{20}$ ILO states that Turkish women's working conditions do not conform with the decent work definition of ILO which are standards and basic rights at work, social dialogue, social security for all and productive employment. Non-discrimination and gender equality are two fundamental principles in labour market which are also the components of ILO's Decent Work Agenda. ${ }^{21}$ In the context of decent work, the conditions and benefits of employment should be equal for both men and women. Besides this, investment in education especially girls' education, opportunities to people with disabilities, skills training, lifelong learning should especially be the core items to strengthen women in labour market. Contrary to these, labour flexibilization such as non-permanent contracts, working from remote, working in informal economy should be minimized or eradicated however it should not be confused with flexicurity-the 'relationship between labour market flexibility and employment security'. ${ }^{22}$ It is very crucial for the employees to work in a permanent, full time jobs (or part-time jobs when needed), benefit from lifelong learning strategies to increase their employability and at the same time benefit from social security systems. Women employability is important in the sense that it may increase the productivity of a company and a country and it is stated that as more women get involved in a labour market the outcome and income of that company/country increases. ${ }^{23}$ So, it shows that women contribute to the competitiveness as well as long term economic growth and development in the labour force. It is an outstanding factor in the labour force to allocate opportunities according to the skills rather than gender. Moreover, women should be assigned to the higher positions both in public and private sector where they can be a role model for other employees. There are some examples for the increasing role of women in some countries around the world in recent years one of

\footnotetext{
${ }^{14}$ Ozturkmen, G. (2021).

${ }^{15}$ Pignatti, Norberto (2016). Encouraging women's labor force participation in transition countries, IZA World of Labor, ISSN 2054-9571, Institute for the Study of Labor (IZA), Bonn, Iss. 264, http://dx.doi.org/10.15185/izawol.264

${ }^{16}$ Inan, F. and Aşık, G. (n.d.). Making Economies Work for Women: Female Labour Force Participation in Turkey. Oxfam/TEPAV.

${ }^{17}$ World Bank (2020). Labour Force Participation Rate, Female (\% of female population ages 15-64), Sweden and Turkey.Retrieved on 9th February 2021, from https://data.worldbank.org/ indicator/SL.TLF.ACTI.FE.ZS?locations=SE

${ }^{18}$ Statistics Sweden (2019). Labour market participation rate higher among both Swedish born and foreign-born persons.

${ }_{19}$ TUIK (2020). Labour Force Statistics, December 2019. News Bulletin 33783.

${ }^{20}$ International Labour Organization (2018). The Gender Gap in Employment: What's Holding Women Back? Retrieved on 6 $6^{\text {th }}$ February 2021, from https://www.llo.org/infostories/en-GB/Stories/ Employment/barriers-women\#intro

${ }^{21}$ International Labour Organization (2007). ABC of Women Workers' Rights and Gender Equality. Geneva: International Labour Office.

${ }^{22}$ International Labour Organization (2007, p.83). ABC of Women Workers' Rights and Gender Equality. Geneva: International Labour Office.

${ }^{23}$ International Labour Organization (2015). Women in Business and Management, Gaining Momentum. Geneva: International Labour Office.
} 
those is Kamala Harris, vice president of the United States. The Prime Minister of Finland, Sanna Marin can be another example for the increasing effect of women in the world. Diversity in management in political and economic areas and letting women to appear in senior positions may lead to favourable solutions and effective outcomes in all kinds of jobs. ${ }^{24}$ Therefore, the representation of women in labour force emerges as a vital phenomenon for all the countries around the world.

This study will investigate labour force representation of women in Sweden and Turkey and will compare these countries according to their extrinsic and intrinsic job quality (extrinsic job quality: earnings and job satisfaction and intrinsic job quality: time at work). The reason why Sweden and Turkey have been selected is the significant difference of the policies among these countries and to show these differences. It may be said that these differences may create an awareness especially in Turkey to create advanced policies in the labour force.

\section{Methodology}

Qualitative research is used in this study. Document analysis, secondary sources are used to clarify the problem. The reason to choose document analysis/ secondary sources is that it saves time and money; easy to access information that already exists; facilitates feasibility of longitudinal and international comparative studies. It also gives opportunity to constitute new perceptions and thus comes up with new conclusions and contributes to the literature. ${ }^{25}$ As the collection of the secondary data takes less time because of ready-to-use information, more time is spent to analyse the data efficiently. After collecting information from the sources, it is easy to make the analysis and interpretation of the data. As this paper is looking from the descriptive point of view it is not possible to assume causality which is the major limitation of this study. In addition, the information found might be too old to be analysed. It is difficult to assess the reliability of the data which refers to the consistency of a measure of a concept. ${ }^{26}$ The reason for this is that there are various interpretations on female underrepresentation in the literature. The data collected may be biased which also affects the reliability of the research. ${ }^{27}$ It might also be difficult to find data related to the subject which is another limitation of this study. As the data are collected by others, the familiarization with the data could be difficult. Additionally, other limitation of the study is the existence of third variable. As the data is collected by others, the researchers may only look to the relationship between two variables, leading to be difficult to make interpretations when third variable is considered. ${ }^{28}$

In this research, cumulative data is also used to compile the maximum information about the subject to be analysed. In this way, it is easy to see the common and segregated points in the literature and perform analysis according to the information. For the data analysis, the sources of World Bank Data, Statistics Sweden, TUIK, Eurostat, OECD, EFILWC, Euro found and other articles and journals were used. These sources give comparable data about Sweden and Turkey. The importance to use comparable data is that it facilitates to see the similarities and differences between the countries. By comparing these two states, it is much more possible to reach an explanation, understanding and further conclusions. ${ }^{29}$ However, in some cases there are limitations of comparable data. For instance, when there is no available source to make comparison of the states, resources from national sites are then used to get the information. Journals and articles are used to reach suitable and reliable information. However, looking to the estimates of countries separately may lead to misleading information because there can be the non-alignment of two sources. For instance, the definitions in the sources may not be same which emerges a comparability problem. Thus, the study tries to refrain from using two different resources to get consistent information.

Descriptive statistics is used in the study to summarize the data in a meaningful way. Since descriptive statistics are used, the research

\footnotetext{
${ }^{24}$ International Labour Organization (2020). Empowering Women at Work: Policies and Practices for Gender Equality in Supply Chains. Geneva: International Labour Office.

${ }^{25}$ Perez, X. and Lopez, S. (2013). Advantages and Disadvantages of Secondary Data Collection Nowadays. Retrieved 28 ${ }^{\text {th }}$ February 2021, from https://xaperezsindin.com/2013/12/11/ advantages-and-disadvantages-of-secondary-data-collection/

${ }^{26}$ Bryman, A. (2012). Social Research Methods. United States: Oxford University Press.

${ }^{27}$ Creswell, J.W. (2013). Qualitative inquiry and research design: Choosing among five approaches, $3^{\text {rd }}$ edn. Los Angeles: Sage Publication.

${ }^{28}$ Bryman, A. (2012). Social Research Methods. United States: Oxford University Press.

${ }^{29}$ Azarian, R. (2011). Potentials and Limitations of Comparative Method in Social Science. International Journal of Humanities, 1(4), 113-125.
} 
does not allow to reach any conclusion about the problem. Descriptive statistics is only a way to describe the data. ${ }^{30}$ The study breaks down the data by gender, education, and occupation to understand if job quality can vary according to these terms. By using descriptive data, it is not possible to make generalization about the data collected which is a limitation for the study. It is only used to make description and interpretation about the data which will be shown in the data analysis. Another limitation of the descriptive statistics is that it cannot infer causality because it is based on certainty. The study tries to explore rather than explain the data. Causality is about actuality rather than possibility. ${ }^{31}$ Spirkin mentions that, in social sciences, it is difficult to reach universal information. There is not any phenomenon that is caused by other phenomenon. There is always additional information that contributes to the literature. The concepts of reason and effect define simultaneous events, Spirkin says. It is stated that every phenomenon is attached to other phenomenon with connections of more than one value. It is therefore not possible to rely on causality in this study as it is based on explorations and need further analysis in the future.

\section{Result}

\section{Earnings}

Regarding earnings, in the EU female workers are generally more exposed to low wages. ${ }^{32}$ Although females are in labour force to a great extent, they accounted for 55.1 percent of low wage workers in 2011. One solution to improve the condition of low wage workers is to increase their pay by establishing good and qualified jobs in the economy. ${ }^{33}$ As Warhust et al point out that the jobs that offer high pays are considered as good and high qualified jobs. ${ }^{34}$

\section{Earnings by Gender}

The gender pay gap is the difference between men's and women's earnings which men's earnings are higher than those of women. The gender pay gap is a common issue in European states: 'On average, women in the EU earn around 14 percent less per hour than men in 2018. ${ }^{35}$ The effect of gender pay gap is that women earn less during their lifetimes, which results in lower pensions and poverty in old ages. The average earning of Swedish man who mostly works in sales is SEK 45,200 per month. ${ }^{36}$ Swedish woman who generally has the highest share of earning in healthcare sector earns average of SEK 28,400 per month. According to DiSK/Genel İş Trade Union (2019), in Turkey, average monthly income of man in higher education is 4,000 TL and it is $2,945 \mathrm{TL}$ for woman in $2017^{37}$ (The minimum net wage in 2017 was reported as 1,404 TL in Turkey)

\section{Earnings by Education}

Many of the studies have shown that education increases the level of earnings. It is stated that educational attainment has a big and considerable effect on earnings of women and men. ${ }^{38}$ A person with a tertiary education can earn over $50 \%$ more than a person with an upper-secondary or post-secondary non-tertiary education. In OECD countries, 'those who do not complete an upper-secondary education could earn an average of $23 \%$ less than their counterparts who complete that level of education'. ${ }^{39}$ Therefore, high level of education increases earnings and in return high earnings indicate high job quality. Eurostat mentions that tertiary education increases employment opportunities. Hourly earnings in educational attainment levels are higher in Sweden than in Turkey. ${ }^{40}$ In both countries when the level of educational attainment increases, the earnings

\footnotetext{
Trochim, W. (2021). Descriptive Statistics. Retrieved $28^{\text {th }}$ February 2021, from https://conjointly.com/kb/descriptive-statistics/

${ }^{31}$ Spirkin, A. (n.d.). The Principle of Causality. Retrieved 28 ${ }^{\text {th }}$ February 2021, from https://www.marxists.org/reference/archive/spirkin/works/dialectical-materialism/ch02-s06.html

${ }^{32}$ Thiess, Rebecca (2012). The Future of Work: Trends and Challenges for Low-Wage Workers. Retrieved $12^{\text {th }}$ September 2020, from https://www.epi.org/publication/bp341-future-of-work/

${ }^{33}$ Thiess, Rebecca (2012). The Future of Work: Trends and Challenges for Low-Wage Workers. Retrieved $12^{\text {th }}$ September 2020, from https://www.epi.org/publication/bp341-future-of-work/

${ }^{34}$ Warhurst, C., Carre, F., Findlay, P. and Tilly, C. (ed) (2013). Are Bad Jobs Inevitable? Trends, Determinants and Responses to Job Quality in the Twenty-First Century. Special Issue on Job Quality, 66(15), 1019-1020.

${ }^{35}$ European Commission (2018). The Gender Pay Gap Situation in the EU. Retrieved $28^{\text {th }}$ February 2021, from https://ec.europa.eu/info/policies/justice-and-fundamental-rights/gender-equality/ equal-pay/gender-pay-gap-situation-eu_en

${ }^{36}$ Sweden Sverige (2020). The Average Swedish Family. Retrieved $12^{\text {th }}$ September 2020, from https://sweden.se/society/meet-the-average-anderssons/\#start

${ }^{37}$ DiSK/Genel Is Trade Union (2019). Report of Women Labour in Turkey. Retrieved 09th November 2019, from http://cloudsdomain.com/uploads/dosya/19288.pdf

${ }^{38}$ Carnoy, M. (1996). Race, Gender, and the Role of Education in Earnings Inequality: An Introduction. Economics of Education Review, 15(3), $207-212$.

${ }^{39} \mathrm{OECD}\left(2011\right.$, p.138). What are the Earnings Premiums from Education? Retrieved $12^{\text {th }}$ September 2020, from http://www.oecd.org/edu/skills-beyond-school/48630790.pd

${ }^{40}$ Eurostat (2019). Employment rates of recent graduates. Retrieved 09th November 2019, from https://ec.europa.eu/eurostat/statistics explained/index.php?title=Employment_rates_of_recent_ graduates\#Employment_rates_of_recent_graduates
} 
also increase. But the impact seems to be higher in Turkey than in Sweden. This may lead us to conclude that if Turkey's educational attainment level is higher its earnings could be higher as well.

\section{Earnings by Sector/Occupation}

'Wages in female dominated sectors and occupations are lower than those in male dominated sectors and occupations'. ${ }^{41}$ For instance, in Sweden men mostly work in sectors as doctors, managers, executives and in financial sectors in which the earnings are high. The understanding is that high paid jobs/ occupations are associated more with men rather than women. The reasons are indicated as 'gender discrimination in the labour market and voluntary selection of men and women into different sectors and occupations' because of their different care responsibilities. ${ }^{42}$

In addition, in Turkey, earnings of men and women differ by occupation as well. The top professions such as corporate managers, life science and health professions and engineering have the highest income ${ }^{43}$ while other professions such as sales and services elementary occupation, agriculture, mining, construction, and manufacturing have low monthly incomes. Generally, men work in high profession jobs for high incomes in Turkey whereas women are behind men in these professions. Women mostly work in services and agriculture sector in Turkey in which they earn less than men and this may lead Turkish women to withdraw from the labour force because low income and unpaid jobs indicate low job quality and may end up with female underrepresentation.

\section{Job Satisfaction}

Job satisfaction concerns individuals' attitudes about their jobs which results from the perception of their jobs. ${ }^{44}$ Job satisfaction affects labour market behaviour, work productivity, work effort. ${ }^{45}$ It is important for an individual well-being and affects people's decisions about staying in or leaving a job. After European policy makers focused on more and better jobs, they also determined job satisfaction as a part of job quality.

\section{Job Satisfaction by Gender}

In table 1, both WES and ULF surveys show that women are more satisfied with their jobs than men in Sweden. Women's high level of job satisfaction in Sweden can be linked to part-time working hours. In addition to this, men's expectations are higher than women. ${ }^{46}$ Men feel that they have more responsibilities because they are attributed as the major breadwinner and therefore, they feel more pressure. ${ }^{47}$

Table 1: Job Satisfaction by Gender in Sweden (\%), 2003

\begin{tabular}{lll}
\hline & \multicolumn{2}{c}{ Satisfied } \\
\cline { 2 - 3 } Survey & Men & Women \\
\hline WES & 71.3 & 73.4 \\
ULF & 75.6 & 81.8 \\
\hline
\end{tabular}

Source: EFILWC, 2007

(WES: Work Environment Survey, ULF: Survey of Living Conditions)

(Note: In Table 1, job satisfaction by gender in Sweden is found out through WES and ULF. WES includes the active population 16-64 years old and the latest publication is 2003. In WES, job satisfaction is tried to be understood by the question: 'How do you experience your work?' IN ULF survey, the question on job satisfaction is more indirect. The question aims to clarify respondents' instrumental attitude to job such as whether people work only for money. The latest data is available from 2002-2003).

\footnotetext{
${ }^{41}$ World Bank (2012, p.205). Gender Differences in Employment and Why They Matter. Retrieved 09th November 2019, from http://siteresources.worldbank.org/INTWDR2012/ Resources/7778105-1299699968583/7786210-1315936222006/chapter-5.pdf

${ }^{42}$ World Bank (2012, p.205). Gender Differences in Employment and Why They Matter. Retrieved 09 ${ }^{\text {th }}$ November 2019, from http://siteresources.worldbank.org/INTWDR2012/ ${ }^{41} 41$ Resources/7778105-1299699968583/7786210-1315936222006/chapter-5.pdf

${ }^{43}$ Ercan, H. (2011). Occupational Outlook in Turkey. Ankara: ILO.

${ }^{44}$ Aydogdu, S. (2011). An Empirical Study of the Relationship Among Job Satisfaction, Organizational Commitment and Turnover Intention. International Review of Management and Marketing, 1(3), 43-53

${ }^{45}$ EFILWC (2007). Measuring job satisfaction in surveys-Comparative analytical report. Retrieved $12^{\text {th }}$ September 2020, from https://www.eurofound.europa.eu/sites/default/files/ef files/ewco/ reports/TN0608TR01/TN0608TR01.pdf

${ }^{46}$ Roeters, A. and Craig, L. (2014). Part-Time Work, Women's Work-Life Conflict and Job Satisfaction: A Cross-National Comparison of Australia, the Netherlands, Germany, Sweden and the United Kingdom. International Journal of Comparative Sociology, Vol n/a, 1-19.

${ }^{47}$ Behar, D. (2019). Women Happier at Work Than Men. Retrieved 09 ${ }^{\text {th }}$ November 2019, from http://www.dailymail.co.uk/news/article-7356/Women-happier-work-men.html
} 
Although there is not much difference between men's and women's job satisfaction in Turkey (Table 2), the slightly lower female job satisfaction could be due to women's difficulty for achieving a satisfactory work-life balance. In addition to this, they work long hours as full-time workers which affects their worklife balance. The other reasons may be indicated as women's bad working conditions, low salaries, and the lack of affordable childcare. ${ }^{48}$

Table 2: Job Satisfaction by Gender in Turkey (\%), 2012

\begin{tabular}{ll}
\hline Gender & Satisfied \\
\hline Women & 70.1 \\
Men & 71.2 \\
\hline
\end{tabular}

Source: Newspaper Milliyet, 2013

\section{Job Satisfaction by Educational Level}

Studies show that there is a direct relationship between education level and job satisfaction which is 'the higher the education level, the higher the degree of job satisfaction'. ${ }^{49}$ Higher level of education presents some advantages to the people in the workplace such as high wages or bargaining power in the market. ${ }^{50}$ Thus, the high level of education increases people's expectation from the jobs which may have positive effect on job satisfaction. This is consistent with EFILWC (2007) that mentions high education increase the possibility of a better job and good working conditions. Job satisfaction related to education has to do with salary (earnings) and career development. Earnings are related to job satisfaction and they are directly proportional. ${ }^{51}$ The other issue about job satisfaction related to education is career development. People who have high level of education expect a career development in their jobs and who have high level of education has more possibility to advance in their careers. This may lead to high job satisfaction especially among men rather than women in Turkey. It is difficult for women to proceed in their careers because their access to education may be difficult compared to men. ${ }^{52}$ The types of jobs that underestimate women decrease the quality of job for women and may lead to withdrawal and underrepresentation of Turkish women in labour force.

\section{Job Satisfaction by Occupation/Sector}

Job satisfaction differs according to the occupation of the employees. It is related with different promotion opportunities and facilities given to employees. ${ }^{53}$ For instance, managers are more satisfied with their jobs than other employees because of the opportunities and benefits of the job. EFILWC (2007) points out that managerial work includes task variety, autonomy and responsibility which increase job satisfaction. Content of the work also increase job satisfaction of employees. ${ }^{54}$ They may also get performancebased pay package which may also increase the satisfaction of the job. This may also be connected to the earnings of the people in these positions. Occupations with high earnings may increase job satisfaction. Table 3 displays the percentage of people in Sweden who are satisfied with their jobs according to the sector.

\section{Table 3: Sector of Employment in Sweden by Job Satisfaction (\%), the WES}

\begin{tabular}{lr} 
Sector of Employment & Satisfied in \\
\hline Financial Intermediation & 77.8 \\
Education & 75.6 \\
Agriculture, forestry & 71.9 \\
Manufacturing & 66.2
\end{tabular}

Source: EFILWC, 2007

The table above shows that while more people are satisfied in financial intermediation, less people in manufacturing sector is satisfied with their jobs. In

\footnotetext{
${ }_{48}$ Sobecki, N. (2010). Turkey's Female Unemployment Problem. Retrieved 13"th September 2020, from http://www.globalpost.com/dispatch/turkey/100225/turkish-women-employment ${ }^{49}$ EFILWC (2007, p.10). Measuring job satisfaction in surveys-Comparative analytical report. Retrieved $12^{\text {th }}$ September 2020, from https://www.eurofound.europa.eu/sites/default/files/ef_files/ ewco/reports/TN0608TR01/TN0608TR01.pdf

${ }^{50}$ Tampieri, A. (2010). Sex and the Uni: Higher Education Effects in Job and Marital Satisfaction. Retrieved 13 $3^{\text {th }}$ September 2020, from http://www.le.ac.uk/ec/research/RePEc/lec/leecon/dp10-07.pdf ${ }^{51}$ Eurofound (2013). Women, Men and Working Conditions in Europe. Luxembourg: Publications Office of the European Union.

${ }^{52}$ Bozkurt, V., Aytac, S., Bondy, J. and Emirgil, B.F. (2011). Job Satisfaction, Role Overload and Gender in Turkey. Istanbul Journal of Sociological Studies, 44, $49-67$.

${ }^{53}$ EFILWC (2007). Measuring job satisfaction in surveys-Comparative analytical report. Retrieved $12^{\text {th }}$ September 2020, from https://www.eurofound.europa.eu/sites/default/files/ef_files/ewco/ reports/TN0608TR01/TN0608TR01.pdf

${ }^{54}$ Zalewska, A. M. (1999). Job Satisfaction and Importance of Work Aspects Related to Predominant Values and Reactivity. International Journal of Occupational Safety and Ergonomics, $5(4), 485-511$.
} 
Sweden, financial sector is one of the important industries that grow rapidly. It is one of the sectors that make considerable contribution to production, employment, and welfare. ${ }^{55}$ In this context, while financial intermediation might have the highest benefits for the employees, manufacturing sector might have the lowest benefits and opportunities.

The studies reveal that the job stability and job security are two important factors in job satisfaction of Turkish workers. ${ }^{56}$ Many workers in Turkey experience job insecurity and therefore keeping a job is an important issue for Turkish workers. It is important because it is usually difficult for people to find another job and finding a job may last so long as the unemployment rates are high in Turkey. There are other factors affecting occupational job satisfaction in Turkey. For instance, women are highly represented in the services sector following the agriculture sector. Although forming an important part, the number of women in agriculture sector is gradually decreasing. Women in Turkey are mostly satisfied in services sector rather than agriculture and industry sector because services sector is considered as 'appropriate to women'. ${ }^{57}$ The services sector provides women some facilities like, shortterm working or temporary working periods, like teaching or nursing. Thus, these features might increase the quality of the job/sector for women and may prevent underrepresentation of them in these occupations. The reason of declining number of women in industry sector is because of deprivation in social security rights.

\section{Intrinsic Job Quality}

Intrinsic job quality is related with the work and its environment. It comprises skill use and discretion, social environment, physical environment, work intensity and working time. In this part, time at work is evaluated. The study tries to explore when people work more, they had less leisure time and less time to care about their family. The study tries to explain that short working hours indicate high job quality and may result in female representation in the labour force.

Working time is one of the important areas of employment in EU Legislation which tries to improve working conditions. ${ }^{58}$ The European Working Time Directive aims to protect the employees from long working hours. The Working Time Directive mentions that there should not be excessive working hours and it should meet minimum standards throughout the EU. For instance, according to the Working Time Directive weekly working hour must not exceed 48 hours on average in EU countries. It tries to prevent any health damage to workers due to long working hours and it aims safety of the workers. ${ }^{59}$ Gash et al mention reduced working hours indicate high job quality and increase job satisfaction. ${ }^{60}$

\section{Time at Work by Gender}

Table 4 shows that Turkish men and women work longer hours than Swedish men and women. Both in Sweden and in Turkey, women's weekly hours of work are less than men. Although the difference of weekly working hours between men and women in Sweden is low, the difference is larger between genders in Turkey.

\section{Table 4: Average Number of Actual Weekly Hours of Work in Main Job by Sex, 2008 (latest year data)}

\begin{tabular}{lcc}
\hline & Men & Women \\
\hline Sweden & 38,6 & 33,9 \\
Turkey & 53,2 & 43,2 \\
\hline
\end{tabular}

Source: Eurostat, 2020

It is important to note that normal working hours for full-time employees is usually 40 hours per full working week in Sweden. ${ }^{61}$ In Turkey, weekly working hours for the full-time employees reach almost 50 hours. ${ }^{62}$

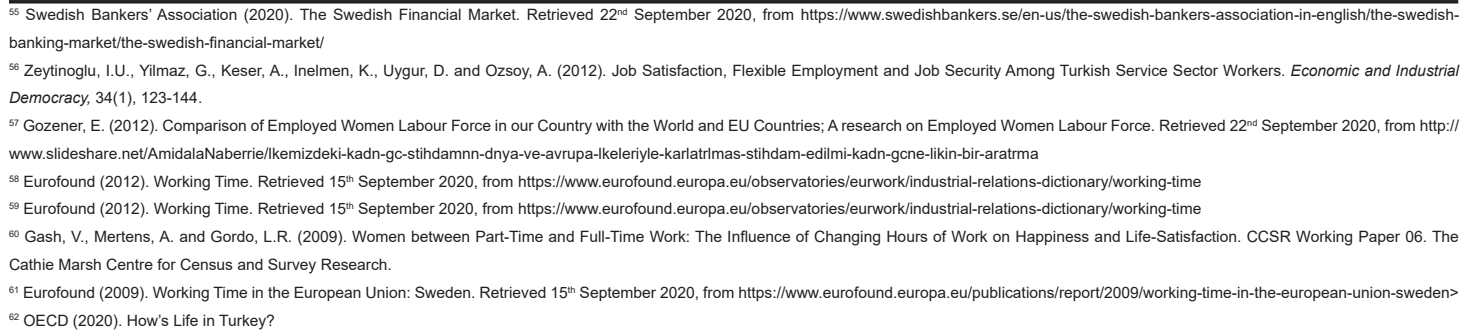




\section{Time at Work by Education}

The education level effects part time and full-time employment. Statistics show that Swedish women mostly work in part-time jobs because mothers tend to work fewer hours especially after having children. ${ }^{63}$

Table 5: Full-Time and Part-Time Employment by sex, age, and educational attainment level (Tertiary Education) (per 1000 people), 15-64 years old, 2019

\begin{tabular}{lcccc}
\hline & \multicolumn{2}{c}{ Part-time } & \multicolumn{2}{c}{ Full-time } \\
\cline { 2 - 5 } & Female & Male & Female & Male \\
\hline Sweden & 302,3 & 112,3 & 917 & 806,2 \\
Turkey & 205,5 & 159,2 & $2,558.5$ & $4,121.8$ \\
\hline
\end{tabular}

Source: Eurostat, 2020

Table 5 shows that part-time employment is more prevalent among Swedish women who have high level of education while education level does not affect the fathers' time at work which they work in fulltime jobs. In full-time employment, Turkish women significantly exceed Swedish women. An outstanding factor about the table is that high educated Swedish women outnumber Swedish men both in part-time and full-time employment. This may show that education level of Swedish women is high which ends up with high rates of women working part and full time. Both in Sweden and in Turkey, women tend to work in full time jobs when the education level increases which means the more educated women are, the more likely they are to work full-time.${ }^{64}$ Both Swedish and Turkish women with high education level work more in full-time jobs because they may not want to spend leisure time. Part time jobs have more leisure time and educated women may not want to spend their time without working.

Part time jobs are important especially for women having children. Despite high rates of Swedish women with high education level work in full-time jobs, they easily access to part-time jobs especially if they have child under the age of $8 .{ }^{65}$ In addition to this, in Turkey, part time jobs are not so prevalent ${ }^{66}$ suggesting that both men and women work mostly in full-time jobs. However, this situation causes difficulties for Turkish women to adjust their work and family life balance which may cause reductions in their performance, productivity, and efficiency at their job. This also may lead to underrepresentation of Turkish women in the labour force.

Table 6: The minutes per day spent in each activity in 24 hours, men age 15-64, latest year

\begin{tabular}{|c|c|c|c|c|c|}
\hline & $\begin{array}{c}\text { Paid Work } \\
\text { or Study }\end{array}$ & $\begin{array}{c}\text { Unpaid work } \\
\text { (routine housework, } \\
\text { shopping, care for } \\
\text { household members, } \\
\text { childcare, adultcare, } \\
\text { care for non-house } \\
\text { hold members, } \\
\text { volunteering) }\end{array}$ & $\begin{array}{l}\text { Personal } \\
\text { Care } \\
\text { (eating, } \\
\text { sleeping, } \\
\text { resting) }\end{array}$ & $\begin{array}{l}\text { Leisure (socializing, } \\
\text { cultural entertainment, } \\
\text { and sports events) }\end{array}$ & $\begin{array}{l}\text { Other (Time spent } \\
\text { in spiritual and } \\
\text { religious activities } \\
\text { and in civic } \\
\text { obligations or in } \\
\text { unspecified activities) }\end{array}$ \\
\hline Sweden & 313 & 171 & 611 & 338 & 7 \\
\hline Turkey & 358 & 68 & 679 & 301 & 34 \\
\hline
\end{tabular}

Source: OECD Family Database, accessed 2 February 2021

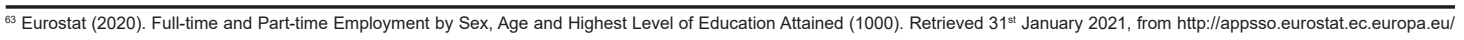
nui/show.do?dataset=lfsa_epgaed\&lang=en

${ }^{64}$ Bjornberg, U. and Dahlgren, L. (2003). Labour Supply: The Case of Sweden. Retrieved 25 ${ }^{\text {th }}$ November 2019, from https://www.york.ac.uk/inst/spru/research/nordic/swedenlabo.pdf ${ }^{65}$ Bjornberg, U. and Dahlgren, L. (2003). Labour Supply: The Case of Sweden. Retrieved 25 $5^{\text {th }}$ November 2019, from https://www.york.ac.uk/inst/spru/research/nordic/swedenlabo.pdf ${ }^{66}$ EFILWC (2011). Part Time Work in Europe. Luxembourg: Publications Office of the European Union.

Eurofound (2010). Gender Wage Inequality. Retrieved 15 $5^{\text {th }}$ September 2020, from http://www.eurofound.europa.eu/ewco/2010/10/SE1010019I.htm
} 
Men's and Women's Time Spent by Activity

The below tables show the minutes per day spent in each activity in 24 hours classified as men and women. In Table 6 men in Sweden work less hours per week in a paid job compared to Turkey. In
Turkey men work longer hours per week. Following this Swedish men spent more time for housework, shopping, care for child and household members and leisure compared to Turkey.

Table 7: The minutes per day spent in each activity in 24 hours, women age 15-64, latest year

\begin{tabular}{|c|c|c|c|c|c|}
\hline & $\begin{array}{c}\text { Paid Work } \\
\text { or Study }\end{array}$ & $\begin{array}{c}\text { Unpaid work } \\
\text { (routine housework, } \\
\text { shopping, care for } \\
\text { household members, } \\
\text { childcare, adultcare, } \\
\text { care for non-house } \\
\text { hold members, } \\
\text { volunteering) }\end{array}$ & $\begin{array}{l}\text { Personal } \\
\text { Care } \\
\text { (eating, } \\
\text { sleeping, } \\
\text { resting) }\end{array}$ & $\begin{array}{l}\text { Leisure (socializing, } \\
\text { cultural entertainment, } \\
\text { and sports events) }\end{array}$ & $\begin{array}{l}\text { Other (Time spent } \\
\text { in spiritual and } \\
\text { religious activities } \\
\text { and in civic } \\
\text { obligations or in } \\
\text { unspecified activities) }\end{array}$ \\
\hline Sweden & 275 & 220 & 633 & 306 & 5 \\
\hline Turkey & 134 & 305 & 685 & 270 & 46 \\
\hline
\end{tabular}

Source: OECD Family Database, accessed 2 February 2021

According to Table 7, Swedish women spend more time in paid work than Turkish women which might be because of underrepresentation of women in paid jobs in Turkey. Therefore, unpaid work, time spent for childcare, housework, shopping is more in Turkey among women compared to Swedish women. Additionally, Turkish women may devote more of their time for personal care and other activities.

\section{Discussion}

Overall, regarding earnings, both Swedish and Turkish men are represented in high paid jobs compared to women. These jobs are considered as male dominated jobs or occupations. Jobs that offer high pays are defined as good and high-quality jobs. Although in Sweden men are dominant in high paid jobs which have high quality, this is not always the case for women because they are sometimes represented in low paid jobs. Although Swedish women work as much as men do, they mostly occupy low paid positions. In Turkey, Turkish women are mostly in low paid jobs and in informal sector and their incomes are less than those of men. Turkish women are much more in unpaid work which may be attributed as low-quality job. These kinds of jobs discourage women to participate in the labour force and therefore can lead to underrepresentation of Turkish women in the labour force. Euro found points out that gender wage inequality is due to unequal distribution of family obligations and different valuation of men's and women's work. ${ }^{67}$ It is stated that women spend more time in household and family issues, and these are considered as unpaid work which may also be further considered as low-quality job. Therefore, where women tend to do more unpaid work, their participation in the labour market may decrease. Finally, women are less eager to invest their skills and efforts to a lowquality job because it will be paid less, and this may result in underrepresentation of Turkish women in the labour force.

Female dominated sectors earn less than male dominated sectors and occupations..$^{68}$ In both Sweden and Turkey, women are underrepresented in some of the occupations (e.g., engineering, managers, and doctors) which are usually associated with men. Thus, the jobs of men and women in Sweden and in Turkey differ to a great extent which leads to underrepresentation of women in labour market. 
Although women try to close this gap by increasing their educational level men still predominantly work and earn more compared to women in the labour market. Even if women work in high paid sectors and occupations, they still dramatically earn less than men. ${ }^{69}$ For instance, Carnevale et al mention that although petroleum engineering is the highest paying among engineering sector, women only form 17 percent of this sector. On the other hand, women form 32 percent of environmental engineering which is the lowest paying sector among engineering. Therefore, this situation alike obliges women to accept to work in low paid jobs even sometimes without any social security. As a result, such a situation causes women to withdraw from the labour market because of not being offered equal situations compared to men and not being given their main rights in the labour force.

Education also affects earnings. In both countries high educated individuals earn more than low educated ones, but the gap is huge in Turkey. Low education does not grant access to qualified and highly paid jobs. Hence, it may lead women not to participate in the labour market. Higher level of education presents some advantages to the people at the workplace such as high wages or bargaining power in the market ${ }^{70}$ indicating that when the education level increases, the satisfaction from the job also increases. The educational level of Swedish women is higher than Turkish women which make them to feel much freer to choose a suitable job for themselves. Compared to Turkish women they are highly represented in the labour force. Increasing education level may lead people to earn more money which indicates high job qual ity, and it may thus increase labour market representation of women.

In Sweden women are more satisfied with their jobs, they appear to be slightly more satisfied than Turkish women. Unlike Swedish women, Turkish women face some disadvantages at work such as long working hours and low salaries. That is why Turkish women have more difficulty to balance their work and family life and this leads them to stop working and underrepresentation in the labour market. High income, promotion and annual leave determine job satisfaction and these factors are higher in Sweden than in Turkey and higher among men rather than women.

These are some factors that indicate low job quality and may end up with under representation of women in the labour force. Education and occupation are also important in job satisfaction. High educated people will expect more earnings and career development. Therefore, an increase in job satisfaction might lead to an increase in representation of female labour force participation.

Turkish men and women work longer hours than Swedish men and women. Working hours of men and women are longer in Turkey than in Sweden. Part-time employment is prevalent among Swedish women. However, after having child, Swedish women access to part-time jobs to balance their work and family life. In Turkey, women mostly work in fulltime jobs rather than part-time and this decreases the performance and production of workers and might end up with underrepresentation of Turkish women in the labour force.

\section{Conclusion}

Overall, this study explores whether job quality affect underrepresentation of women in the labour force. It is seen that the indicators of job quality which are earnings, job satisfaction and time at work have different effects on female representation. Turkey lags behind Sweden in all these factors and should present some effort to reach the level of Sweden which is also important to adapt itself to EU regulations. Enhancing social security rights (especially for women), giving opportunities for women in the labour force, decreasing unregistered employment and undeclared work, increasing education, developing working conditions that end up with job satisfaction of workers increase the job quality and therefore lead to high representation of women in the labour force. As mentioned above Turkey and Sweden differ economically and socially so the level of income (jobs), education and health of people are different in these countries. In this point it is important to note that varying social and economic characteristics of Turkey and Sweden cause different labour force representation of women in these countries. 
Within the 2023 Strategy, Turkey aims to increase employment which will facilitate women to enter labour market. However, these policies should be consistent and permanent. The Turkish Employment Agency (ISKUR) should foster its policies to increase participation of women in the labour market. Social security systems should be controlled and applied in all organizations which usually exclude women and result in underrepresentation of women in the labour force. If Turkey implements policies that compete Sweden and if a legal enforcement is advanced through social and employment policies, the wellbeing of Turkish women in the labour market would enhance. Taken together, enhancing social security rights (especially for women), giving opportunities for women in the labour force, decreasing unregistered employment and undeclared work, enhancing education policies, developing working conditions that end up with job satisfaction of workers increase job quality and therefore lead to high representation of women in the labour force.

\section{Funding}

No grant is provided for this article. The author is an independent researcher.

\section{Conflict of interest}

There is no conflict of interest for this article.

\section{References}

1. Aydogdu, S. (2011). An Empirical Study of the Relationship Among Job Satisfaction, Organizational Commitment and Turnover Intention. International Review of Management and Marketing, 1(3), 43-53.

2. Azarian, R. (2011). Potentials and Limitations of Comparative Method in Social Science. International Journal of Humanities, 1(4), 113-125.

3. Behar, D. (2019). Women Happier at Work Than Men. Retrieved 09th November 2019, from http://www.dailymail.co.uk/news/article-7356/ Women-happier-work-men.html

4. Bjornberg, U. and Dahlgren, L. (2003). Labour Supply: The Case of Sweden. Retrieved $25^{\text {th }}$ November 2019, from https://www.york.ac.uk/ inst/spru/research/nordic/swedenlabo.pdf

5. Bozkurt, V., Aytac, S., Bondy, J. and Emirgil, B.F. (2011). Job Satisfaction, Role Overload and Gender in Turkey. Istanbul Journal of Sociological Studies, 44, 49-67.

6. Bryman, A. (2012). Social Research Methods. United States: Oxford University Press.

7. Carnevale, A. P., Smith, N., \& Gulish, A. (2018). Women can't win: Despite making educational gains and pursuing high-wage majors, women still earn less than men.

8. Carnoy, M. (1996). Race, Gender, and the Role of Education in Earnings Inequality: An Introduction. Economics of Education Review, 15(3), 207-212.

9. Catalyst (2020). Women in the WorkforceGlobal: Quick Take. Retrieved on 6th February
2021, from https://www.catalyst.org/research/ women-in-the-workforce-global/

10. Creswell, J.W. (2013). Qualitative inquiry and research design: Choosing among five approaches, $3^{\text {rd }}$ edn. Los Angeles: Sage Publication.

11. Dahl, S., Nesheim, T. and Olsen, K.M. (2009). Quality of work - concept and measurement. Retrieved on $12^{\text {th }}$ September 2020, from https:// era.ed.ac.uk/bitstream/handle/1842/3146/RECWP_0509_Dahl_Nesheim_Olsen.pdf;jsessioni $\mathrm{d}=576 \mathrm{F0E} 1 \mathrm{C} 7 \mathrm{D} 45 \mathrm{~F} 7112 \mathrm{~B} 49 \mathrm{~A} 81248 \mathrm{AF} 4 \mathrm{A66}$ ? sequence $=1$

12. DiSK/Genel İş Trade Union (2019). Report of Women Labour in Turkey. Retrieved 09th November 2019, from http://cloudsdomain.com/ uploads/dosya/19288.pdf

13. EFILWC (2007). Measuring job satisfaction in surveys-Comparative analytical report. Retrieved $12^{\text {th }}$ September 2020, from https:// www.eurofound.europa.eu/sites/default/files/ef_ files/ewco/reports/TN0608TR01/TN0608TR01. pdf

14. EFILWC (2011). Part Time Work in Europe. Luxembourg: Publications Office of the European Union.

15. Ercan, H. (2011). Occupational Outlook in Turkey. Ankara: ILO.

16. Eurofound (2009). Working Time in the European Union: Sweden. Retrieved $15^{\text {th }}$ September 2020, from https://www.eurofound. europa.eu/publications/report/2009/workingtime-in-the-european-union-sweden 
17. Eurofound (2010). Gender Wage Inequality. Retrieved $15^{\text {th }}$ September 2020, from http:// www.eurofound.europa.eu/ewco/2010/10/ SE1010019l.htm

18. Eurofound (2012). Working Time. Retrieved $15^{\text {th }}$ September 2020, from https://www.eurofound. europa.eu/observatories/eurwork/industrialrelations-dictionary/working-time.

19. Eurofound (2013). Women, Men and Working Conditions in Europe. Luxembourg: Publications Office of the European Union.

20. European Commission (2018). The Gender Pay Gap Situation in the EU. Retrieved 28th February 2021, from https://ec.europa.eu/ info/policies/justice-and-fundamental-rights/ gender-equality/equal-pay/gender-pay-gapsituation-eu_en.

21. Eurostat (2020). Full-time and Part-time Employment by Sex, Age and Highest Level of Education Attained (1000). Retrieved 31 st January 2021, from http://appsso.eurostat. ec.europa.eu/nui/show.do?dataset=Ifsa_ epgaed\&lang=en.

22. Eurostat (2019). Employment rates of recent graduates. Retrieved 09th November 2019, from https://ec.europa.eu/eurostat/statistics explained/index.php?title=Employment_rates_ of_recent_graduates\#Employment_rates_of_ recent_graduates.

23. Eurostat (2015). Quality of Life: Facts and views. Luxembourg: Publications Office of the European Union.

24. FAWCETT (Working for Women's Rights since 1866) (2013). The Changing Labour Market: Delivering for Women, Delivering for Growth. Retrieved on $12^{\text {th }}$ September 2020, from https:// www.fawcettsociety.org.uk/the-changinglabour-market-delivering-for-women-deliveringfor-growth.

25. Gash, V., Mertens, A. and Gordo, L.R. (2009). Women between Part-Time and Full-Time Work: The Influence of Changing Hours of Work on Happiness and Life-Satisfaction. CCSR Working Paper 06. The Cathie Marsh Centre for Census and Survey Research.

26. Gozener, E. (2012). Comparison of Employed Women Labour Force in our Country with the World and EU Countries; A research on Employed Women Labour Force. Retrieved 22nd September 2020, from http://www. slideshare.net/AmidalaNaberrie/lkemizdeki- kadn-gc-stihdamnn-dnya-ve-avrupa-lkeleriylekarlatrlmas-stihdam-edilmi-kadn-gcne-likinbir-aratrma.

27. International Labour Organization (2007). ABC of Women Workers' Rights and Gender Equality. Geneva: International Labour Office.

28. International Labour Organization (2015). Women in Business and Management, Gaining Momentum. Geneva: International Labour Office.

29. International Labour Organization (2018). The Gender Gap in Employment: What's Holding Women Back? Retrieved on $6^{\text {th }}$ February 2021, from https://www.ilo.org/infostories/en-GB/ Stories/Employment/barriers-women\#intro

30. İnan, F. and Aşık, G. (n.d.). Making Economies Work for Women: Female Labour Force Participation in Turkey. Oxfam/TEPAV.

31. Jaumotte, F (2004). Labour Force Participation of Women: Empirical Evidence on the Role of Policy and Other Determinants in OECD Countries. Retrieved on $12^{\text {th }}$ September 2020, from http://www.oecd.org/social/ labour/34562935.pdf

32. OECD (2011). What are the Earnings Premiums from Education? Retrieved $12^{\text {th }}$ September 2020, from http://www.oecd.org/edu/skillsbeyond-school/48630790.pdf

33. OECD (2020). How's Life in Turkey?

34. Pignatti, Norberto (2016). Encouraging women's labor force participation in transition countries, IZA World of Labor, ISSN 2054-9571, Institute for the Study of Labor (IZA), Bonn, Iss. 264, http://dx.doi.org/10.15185/izawol.264

35. Perez, X. and Lopez, S. (2013). Advantages and Disadvantages of Secondary Data Collection Nowadays. Retrieved $28^{\text {th }}$ February 2021, from https://xaperezsindin.com/2013/12/11/ advantages-and-disadvantages-of-secondarydata-collection/

36. Roeters, A. and Craig, L. (2014). Part-Time Work, Women's Work-Life Conflict and Job Satisfaction: A Cross-National Comparison of Australia, the Netherlands, Germany, Sweden and the United Kingdom. International Journal of Comparative Sociology, Vol n/a, 1-19.

37. Sobecki, N. (2010). Turkey's Female Unemployment Problem. Retrieved $13^{\text {th }}$ September 2020, from http://www.globalpost. com/dispatch/turkey/100225/turkish-womenemployment 
38. Spirkin, A. The Principle of Causality. Retrieved 28th February 2021, from https://www.marxists. org/reference/archive/spirkin/works/dialecticalmaterialism/ch02-s06.html

39. Statistics Sweden (2019). Labour market participation rate higher among both Swedish born and foreign-born persons.

40. Sweden Sverige (2020). The Average Swedish Family. Retrieved $12^{\text {th }}$ September 2020 , from https://sweden.se/society/meet-the-averageanderssons/\#start

41. Swedish Bankers' Association (2020). The Swedish Financial Market. Retrieved 22nd September 2020, from https://www. swedishbankers.se/en-us/the-swedishbankers-association-in-english/the-swedishbanking-market/the-swedish-financial-market/

42. Tampieri, A. (2010). Sex and the Uni: Higher Education Effects in Job and Marital Satisfaction. Retrieved $13^{\text {th }}$ September 2020, from http:// www.le.ac.uk/ec/research/RePEc/lec/leecon/ dp10-07.pdf

43. Thiess, Rebecca (2012). The Future of Work: Trends and Challenges for Low-Wage Workers. Retrieved $12^{\text {th }}$ September 2020, from https:// www.epi.org/publication/bp341-future-of-work/

44. Torun, E. H. L. I. N. A. Z. (2010). Socioeconomic status of women according to development levels of countries and structure in Turkey. African journal of agricultural research, 5(11), 1154-1161.

45. Trochim, W. (2021). Descriptive Statistics.
Retrieved $28^{\text {th }}$ February 2021, from https:// conjointly.com/kb/descriptive-statistics/

46. TUIK (2020). Labour Force Statistics, December 2019. News Bulletin 33783.

47. Warhurst, C., Carre, F., Findlay, P. and Tilly, C. (ed) (2013). Are Bad Jobs Inevitable? Trends, Determinants and Responses to Job Quality in the Twenty-First Century. Special Issue on Job Quality, 66(15), 1019-1020.

48. World Bank (2020). Labour Force Participation Rate, Female (\% of female population ages 1564), Sweden and Turkey. Retrieved $9^{\text {th }}$ February 2021, from https://data.worldbank.org/indicator/ SL.TLF.ACTI.FE.ZS?locations=SE

49. World Bank (2012). Gender Differences in Employment and Why They Matter. Retrieved 09 ${ }^{\text {th }}$ November 2019, from http://siteresources. worldbank. org/INTWDR2012/Resources /7778105-1299699968583/77862101315936222006/chapter-5.pdf

50. Zalewska, A. M. (1999). Job Satisfaction and Importance of Work Aspects Related to Predominant Values and Reactivity. International Journal of Occupational Safety and Ergonomics, 5(4), 485-511.

51. Zeytinoglu, I.U., Yilmaz, G., Keser, A., Inelmen, K., Uygur, D. and Ozsoy, A. (2012). Job Satisfaction, Flexible Employment and Job Security Among Turkish Service Sector Workers. Economic and Industrial Democracy, 34(1), 123-144. 